\title{
Multilevel cooperation in the EU resolution of cross-border bank groups: lessons from the non-euro area Member States joining the Single Resolution Mechanism (SRM)
}

\author{
Agnieszka Smoleńska ${ }^{1,2}$ D
}

Accepted: 24 May 2021 / Published online: 30 June 2021

(c) The Author(s) 2021

\begin{abstract}
Cross-border banking presents a unique set of challenges in the EU from the perspective of arranging administrative oversight structures. Structuring cooperation between different EU and national authorities in a way which is conducive to trust-building and mutual engagement is an essential condition for overcoming disintegrative tendencies in the internal market. To assess how the existing EU arrangements fare in this regard in the context of EU resolution law, this article comparatively analyses the different models of multilevel administrative cooperation in the post-crisis EU framework. These are specifically the centralised model of the European Banking Union (Single Resolution Mechanism) and the relatively looser networked model of the resolution colleges. The multilevel cooperation under both models is nuanced given the distinct roles of the national resolution authorities, EU agencies and the differentiated status of non-euro area Member States in the EBU (Croatia, Bulgaria). The article's findings allow to identify specific problems of constitutional nature pertaining to the accountability of administrative cooperation, equality of Member States and the implications of Meroni doctrine's distortive effects.
\end{abstract}

Keywords Cross-border banking $\cdot$ Banking union · Non-euro area countries · Resolution · Financial stability $\cdot$ Single resolution mechanism

\section{Introduction ${ }^{1}$}

Cross-border banking presents a unique set of problems from the point of view of arranging EU oversight. Banks operating across a number of Member States can be highly integrated in terms of their management, strategy and cash flows. However, their distinct parts operating in different Member States, either as integrated outposts (branches) or separate legal entities connected through ownership (subsidiaries), ${ }^{2}$ may be perceived differently in terms of their riskiness or significance to the public interest when viewed from the parent company at top of the company hierarchy (the home Member State) or from the local market (the host Member State). The subjective perception of risk in the context of EU-wide or local financial stability has been the source of challenges in arranging cross-border cooperation

Agnieszka Smoleńska

agnieszka.smolenska@ebi-europa.eu

European Banking Institute, Frankfurt, Germany

2 European University Institute, Florence, Italy of authorities overseeing such multinational EU banks. Joint oversight across a number of Member States needs to assuage the concerns of different national authorities which in the absence of safeguards or adequate trust revert to ringfencing and other measures protecting the local market. Such interventions result in fragmentation, undermining the internal market and foregoing the benefits of integration.

\footnotetext{
1 This article benefitted from the insightful comments of Diane Fromage, Mariolina Eliantonio, Kathryn Wright, Jakub Kerlin and other participants of the University of Maastricht and University of York joint workshop "Constitutional Challenges in the Field of Financial Regulation" which took place on 19 October 2020 as well as Dalvinder Singh and Marta Božina Beroš and other participants at the University of Zagreb's conference "EU Financial Regulation and Markets: Beyond Fragmentation and Differentiation" which took place on 26-27 November 2020 as well as two anonymous reviewers. Any errors remain my own.

${ }^{2}$ Branches of a bank in another EU country remain an integral part of the parent bank established in another Member State. Subsidiaries are meanwhile separate legal entities linked with the parent through ownership and control relations, integrated in terms of group management, however subject to host country supervision. A key difference resides in their access to the local safety nets, whereas subsidiaries
} 
Structuring of administrative cooperation in a way which is conducive to trust-building and mutual engagement is an essential condition for overcoming disintegrative tendencies. But which multilevel design yields best results? Is centralisation always superior or are looser forms of cooperation better at creating trust? The design of the post-crisis resolution framework creates a unique opportunity for a comparative assessment of different models of administrative cooperation in this regard.

With the creation of the European Banking Union (EBU) and the overhaul of the European Union's (EU) bank regulation framework since the Great Financial Crisis of 2008, two types of multilevel administrative structures tasked with bank crisis preparation and management (resolution law) across the EU's internal market have been created. Within the EBU, this is the highly integrated and centralised Single Resolution Mechanism, SRM. For the EU as a whole, the less integrated and network-like resolution colleges have been put in place. Both arrangements are subject to an additional layer of complexity, where even in horizontal contexts, they allow for differentiation between national regulatory authorities (NRAs) depending on whether they are members of the euro area or not, or which part of the bank they are responsible for. Such complexity became realised with the entry of Croatia and Bulgaria into close cooperation with the EBU in October 2020 as a precondition to their euro area membership. This article analyses the different models of national and EU public authority cooperation in EU resolution law. It further assesses their relative suitability to achieve their goals in relation to the objectives of relevant EU law and discusses the constitutional conundrums which arise.

To this end, this article proceeds as follows. Section "Cross-border bank resolution in the EU: falling short" reviews the evidence of how the administrative structures at EU and EBU levels with regard to EU resolution law operate in practice and formulates the article's puzzle to be answered. Section "Multilevel cooperation in the EU cross-border bank resolution: between centralisation and networks" comparatively analyses the set-up of multilevel administrative structures established for resolution of crossborder bank groups in the EU and the EBU, in particular explaining their respective complexity. Section “Explaining the outcomes of multilevel administrative cooperation" discusses possible explanations for the different results achieved across the administrative structures. Section "Conclusions"

Footnote 2 (continued)

rely on the home country guarantee schemes, branches fall within the scope of the host country framework. For definitions see arts. 4(1) (16) and (17) CRR Regulation [27]. See further Directive 2014/49/ EU [23]. concludes and discusses the implications and possible constitutional problems arising from the article's findings.

\section{Cross-border bank resolution in the EU: falling short}

Since the Great Financial Crisis new regulatory tools were created to be wielded by the new bespoke authorities (resolution authorities) to address the lack of administrative capacity for management of cross-border banking crises [13]. Their responsibilities differ from those of regular supervisors who concentrate on monitoring the day-to-day performance, safeness and soundness of the bank. By contrast, resolution law allows for both crisis management and ex ante preparation for bank failure by pre-allocating losses, removing specific impediments which are the source of the "too-big-to-fail" problems and establishing playbooks for how a failure would be (publicly) managed. In addition, and remedying a pre-crisis lacuna, the 2014 Bank Resolution and Recovery Directive (BRRD) [24], which applies to all EU Member States, created a new form of cross-border cooperation, namely resolution colleges. These integrated administrative structures are charged with implementation of BRRD rules and tasks related to ex ante bank crisis prevention and management of crises with regard to individual cross-border bank groups. In the context of EBU, the establishment of a more centralised mechanism for supervision (Single Supervision Mechanism, SSM), laid the groundwork for the subsequent creation of an analogous mechanism for resolution, namely the SRM [28]. The SRM, as this article shall discuss, is formally significantly more integrated than the resolution colleges, for example, through the centralised decision-making. However, there are significant flaws in its design, which as the empirical evidence suggests, preclude full attainment of SRM's regulatory objectives. Some such flaws become amplified in the context of adherence of noneuro area Member States to the mechanism. As a first step in the analysis, I review the objectives, means and outcomes of BRRD and SRM in the cross-border context.

\section{Objectives}

In the aftermath of the widespread bank bailouts, resolution was created as a procedure to reinstall market discipline, protect creditors, investors, depositors, taxpayers and the real economy from the instability caused by financial collapse [24 Art. 32(1), 28 Art. 14]. BRRD and SRM set up the administrative framework within which these objectives are to be attained. Specifically, in a cross-border context at the EU and EBU levels, respectively, they seek to achieve a number of specific objectives with regard to managing 
bank failure, facilitating market integration and improving legal certainty.

With regard to managing cross-border bank failure, the BRRD requires an $e x$ ante definition of resolution strategy of the bank (that is the decision on how different procedures across Member States involved would relate to each other in terms of failure) and the removal of impediments to the bank's resolvability (that is any specific obstacles to smooth cross-border cooperation) [24 Art. 10 on resolution planning and Art. 17 on powers to remove impediments to resolvability]. The definition of resolution strategy of the cross-border bank implies choosing whether it would be resolved as a single entity (so-called Single Point of Entry, SPOE approach) or whether distinct entities would be dealt with separately (so-called Multiple Point of Entry, MPOE approach) [30]. In the case of the former, all coordination of bank crisis management is done by a single authority of the state where the parent entity is established. Decisions of this authority then have legal effects across all jurisdictions where the bank is active. In the case of the latter, multiple authorities cooperate with each other, but remain responsible for "their" part of the bank. From a supranational perspective, SPOE is preferable in terms of overall efficiency of resolution [33]; however, it requires significant trust between authorities in addition to a suitable cross-border group structure, if the $e x$ ante resolution plan is to be followed once the crisis occurs [31 p. 44]. Over the course of the GFC, lack of trust between authorities resulted in ring-fencing of national parts of a cross-border bank, which subsequently increased the overall costs of crisis management and persistent market fragmentation. Consequently, improving cooperation between NRAs is in fact a key objective of both BRRD and SRM. In the context of SRM, one of the objectives of centralisation is specifically to improve efficiency of cross-border bank failure [28 Recitals 9-10]. Second, the establishment of a common cross-border resolution framework is meant to facilitate greater market integration and protection of financial stability and critical functions provided by banks, in order to improve the outcomes for the consumers and clients [ 28 Recital 4]. Finally, establishing a new common procedure for dealing with bank failures is to improve legal certainty, especially in a cross-border setting [24 Recital 3, 28 Recital 1].

\section{Means}

With a view to achieving these objectives, the EU resolution law establishes dedicated procedures oriented at achieving $e x$ ante preparedness (resolution plans) as well as specific tools of crisis management (resolution). The latter allow that in the event, the bank is deemed failing or likely to fail and resolution is necessary in the public interest, resolution authorities can take over bank management. Within the EBU, such procedures are centralised, within the EU-coordinated, albeit with a possibility for defection. ${ }^{3}$ In normal times, however, the main task of resolution authorities is preparing $e x$ ante resolution plans outlining possible courses of action if a bank should fail. The content of such plans is specified under the BRRD to include: a demonstration of how critical functions and core business lines could be legally and economically separated from other functions so as to ensure their continuity ("continuity of critical functions"), provisions for the financing of resolution without public support (including Emergency Liquidity Assistance facilities provided by central banks), a description of critical interdependencies of the bank as well as an external communication plan [24 Art. 17]. Further they include the determination of a number of key regulatory requirements, such as the minimum requirement of bailinable debt the bank is to hold (Minimum Requirement of Own Funds and Eligible Liabilities, MREL) and an assessment of the resolvability of the bank (i.e. whether it can be safely dealt with in crisis) [22 Art. 45 as amended, 25 Art. 12 as amended]. Resolution authorities have then the powers to require changes in the current bank operation if it threatens its resolvability and sanction for non-compliance with the requirements they impose on the banks, e.g. by imposing a prohibition on distributions such as dividends [22 Art. 16a, 25 Art. 10a]. These requirements apply both to integrated banks as well as bank groups composed of multiple legal entities. For cross-border bank groups active across a number of Member States, the BRRD and SRM provide for an elaborate framework of cooperation between the NRAs and EU level spanning, as discussed below, highly integrated structures for EBU and more loose arrangements for the EU as a whole. Cross-border bank group's resolution plans are not only to prepare the credit institution for a crisis, but also to ex ante align NRAs' expectations of how bank failure could play out and improve their mutual understanding of sensitivities so as to enable greater trust and productive cooperation should an actual failure of a cross-border bank group occur. The organisation of the preparation of such group plans is, however, organised differently in EBU and EU as a whole.

\section{Outcomes}

It might be assumed that centralised structures might be more conducive to integrated outcomes, for example, with regard to resolution strategies. However, it is not only within the EBU that SPOE is the preferred strategy for cross-border banks of the resolution authorities, but rather across the internal market as a whole [38 p. 26]. Further,

\footnotetext{
${ }^{3}$ Compare Art. 18 on the resolution procedure in SRM and Art. 91 BRRD group resolution scheme preparation, not characterised as a procedure.
} 
fragmentation has persisted as has ring-fencing of crossborder banks within the EBU $[1,14,41]$. Textbook bank resolution, meanwhile, appears to have been implemented mostly outside of the EBU, rather than inside [44]. While the SRB has deferred to national orders and private solutions, first full-blown resolution cases have been carried out in Croatia, before it entered into close cooperation. Meanwhile outside the EBU, there are many examples of successful cooperation in crisis management on a cross-border basis in the Nordics [8].

Why does centralisation within EBU appear not to yield the expected results? Scholars have answered this question-directly and indirectly-from a variety of vantage points. The first set of explanations looks to the incompleteness of EBU, highlighting especially the absence of a common deposit insurance and backstop limitations. Such incompleteness manifests equally as persistent obstacles to intra-group capital flows or shortcomings in the design of resolution tools, such as the bail-in tool, which impede SRM's ability to meet objectives [46]. The second set of explanations has drawn on political economy. Despite centralisation, national interest reigns over best laid plans of EU agencies. This is in particular where the interest of large banks is involved [11]. Thirdly, the legal scholarship has focussed on limits on the powers of the core of the SRM due to constitutional limits drawn by the Meroni doctrine [39]. This article builds on this final approach exploring in addition the complex features of the different integrated administrative structures. ${ }^{4}$

\section{Multilevel cooperation in the EU cross-border bank resolution: between centralisation and networks}

Two distinct forms of EU integrated multilevel procedural cooperation can be distinguished with regard to the implementation of resolution law tasks and oversight over crossborder bank groups with respect to crisis prevention and management [34 p. 166]. They cover analogous procedures which organise the cooperation of NRAs responsible for different parts of a cross-border bank either within the EBU or for the EU as a whole. For the EBU countries, the SRM provides for centralised cooperation of national authorities with the "specific" EU agency (Single Resolution Board, SRB) at its core. ${ }^{5}$ For the EU as a whole (encompassing, therefore,

\footnotetext{
4 As a precondition for joining the euro area, the Eurogroup has requested that Croatia and Bulgaria join the EBU in order to enter the Exchange Rate Mechanism II (ERMII) [12 for comment].

5 Art. 41(1) SRM states that: "The Board shall be a Union agency with a specific structure corresponding to its tasks".
}

the EBU but as well NRAs in other Member States), relatively loose networked arrangements known as resolution colleges are established. Both forms include both horizontal (national) and vertical (national-EU) dimensions of the administrative cooperation, which have, however, some important nuances. As shall be further explained below, complexity arises in the context of differentiated positions of NRAs along the horizontal dimension with regard to their powers and responsibilities within the administrative cooperation procedures. This section outlines the design of SRM and resolution colleges. It covers as well the design of the building blocks of administrative multilevel structures, namely the NRAs (the national level) as well as the European Banking Authority (EBA) the EU agency playing a role in ensuring consistency across the overall regime.

\section{National resolution authorities (NRAs)}

The BRRD requires that each Member State set up an NRA. BRRD allows for these to be delegated to central banks, other public authorities, and-in some cases-also supervisors, though there must be adequate structural arrangements in place to ensure "operational independence" and prevent conflicts of interest [24 Art. 3(3)]. Few Member States had authorities with a specific crisis management mandate before the BRRD and there is no dominant model which has been adopted, with Member States-both euro and not-equally split between central banks and independent agencies acting as the NRAs. ${ }^{6}$ Within the EBU (i.e. including the non-euro Croatia and Bulgaria), there are 10 NRAs which are specialised (i.e. housed within the banking supervisor or a separate institution, in Austria, Estonia, Finland, France, Germany, Latvia, Luxembourg, Malta, Slovakia, Spain), while in 11 Member States it is the national central bank that also acts as the principal NRA (Belgium, Bulgaria, Croatia, Cyprus, Greece, Ireland, Italy, Lithuania, Netherlands, Portugal, Slovenia). The remaining six non-euro Member States equally opt either for the central bank (Czechia, Hungary, Romania) or a separate authority (Denmark, Sweden, Poland). This heterogeneity is important as it may partly explain different sensitivities of NRAs. Across various multilevel cooperation arrangements, the NRAs remain involved in decisionmaking and maintain the implementation powers.

\footnotetext{
${ }^{6}$ See list of resolution authorities published online by the EBA pursuant to Art. 3 (11) of Directive (2014/59/EU), https://www.eba. europa.eu/-/eba-publishes-list-of-designated-resolution-authorities (accessed 13 November 2020).
} 


\section{Resolution colleges}

For cross-border bank groups active across the EU, the primary form of administrative cooperation is the "European resolution colleges" [22 as amended]. For banks operating globally, these cover the part active in the EU, where recently an obligation to establish an EU parent undertaking was introduced [45 for a critical comment]. Colleges are established for each cross-border bank group with a view to producing joint decisions on ex ante resolution plans and resolution schemes should the bank be failing [22 Art. 89 as amended, 32 and 54 on group resolution]. Each college boasts broad membership spanning the group-level NRA, NRAs in countries where the bank has subsidiaries and branches, NRA of the parent financial holding company, relevant supervisors, central bank(s), competent ministries, deposit guarantee authorities and EBA representatives. Such broad membership reflects their aim to allow for an efficient, timely, clearly defined resolution, where due consideration is given to the economies of all states where the bank is active, and action is underpinned by "recognition that coordination and cooperation are most likely to achieve a result which lowers the overall costs of resolution." 7 The broad membership reflects the will to overcome siloed thinking and information gaps prevalent during the financial crisis [4]. ${ }^{8}$

Formally resolution colleges are "not decision-making bod[ies]," but rather dedicated fora for the NRAs to work towards implementing a set of specific procedures relating to $e x$ ante crisis prevention and management. ${ }^{9}$ Individual decisions are taken, enforced and challengeable in national jurisdictions of the NRAs participating. The colleges' role is specifically limited by reference to proportionality as a cooperation arrangement; they are meant to be "less intrusive" than full centralisation [32 p. 165]. These formal provisions of the BRRD, however, are somewhat at odds with the prescription that through cooperation in the college the NRAs are to arrive at a set of joint decisions on resolution plans and-if part of the bank is deemed failing or likely to failjoint resolution schemes. Further, their preparation is highly proceduralised and regulated. In addition to the BRRD rules, the European Commission's Delegated Regulation

\footnotetext{
7 According to recital (98) of the BRRD, 'The resolution college should not be a decision-making body, but a platform facilitating decision-making by national authorities. The joint decisions should be taken by the national authorities concerned' [24 Art. 87(j)].

${ }^{8}$ On the specific role of resolution colleges as information building in the light of the crisis-exasperating lack of information see: Carmassi and Herring [9].

9 Recital 98 BRRD "The resolution college should not be a decisionmaking body, but a platform facilitating decision-making by national authorities. The joint decisions should be taken by the national authorities concerned".
}

No 2016/1075 specifies the internal procedures (e.g. communication and information exchange requirements), while further "written arrangements" are to be developed by the group-level NRA [19 Art. 50].

As a result, the framework within which the NRAs in a college develop the joint decisions on a bank group resolution plan is highly prescriptive. Further, in practice, the joint decisions (or their absence) have a significant impact on the cross-border risk distribution in a bank group since they may cover administrative decisions that the bank remove specific impediments to resolvability (e.g. through changes to the legal or operational structure of a bank), determination of MREL, and the resolution strategy identified [39]. Through cooperation within the colleges the NRAs and the bank may as well decide on frameworks of intra-group stabilisation support in case of failure. ${ }^{10}$ According to the EBA's 2019 Report, generally resolution colleges have been successful with regard to delivering on the joint resolution plans, notwithstanding early cases where EBA mediation-discussed below-was required. ${ }^{11}$

With regard to resolution proper, the BRRD equally provides for a framework around which joint decisions of the college would be taken. However, given the possible fiscal implications of bank failure and the absence of a centralised fund, ${ }^{12}$ it remains flexible. For example, NRAs may withdraw from cooperation, that is not participate in the process of formulating a joint decision, in cases where national financial stability is a concern. The obligation to cooperate is in such an event substituted by transparency requirements [24 Arts. 91 and 92 supplemented by Resolution College RTS].

Three aspects make the resolution colleges a multilevel arrangement rather than purely horizontal cooperation. First, the procedures foreseen by the BRRD and detailed in EBA's delegated rules, grant a special role to the group-level NRA, that is the authority of the Member State where the parent entity of the cross-border bank is established. Second, there is a specific "cross-border"/European mandate which the colleges create for the NRAs. Third, EBA is the EU agency charged with detailing the rules of cooperation of the colleges, as well as solving specific problems which may occur within them.

The first aspect, that is the special role of group-level NRA, is evident, for example, in the process of "mapping"

\footnotetext{
${ }^{10}$ Any such ex ante burden-sharing arrangements remain highly contentious due to fiscal implications of bank failure, i.e. possibility of taxpayer funded bank bailouts.

11 On discussion of problems faced by small hosts (also from the SRB side), see FinSAC [31]. Recent evidence suggests learning and more cooperative outcomes, see EBA [17].

12 Compare with the discussion of the Single Resolution Fund (SRF) below.
} 
the college, that is the set of detailed procedural rules which outline how the college is to be constituted. BRRD confers specific responsibilities on it here, such as the identification of the relevant regulatory architecture for the banking sector in the countries where the given bank group is active as well as the relative importance of the entity (subsidiary or a branch, in accordance with the locally relevant criteria for importance) [24 Art. 88(5)(e)]. ${ }^{13}$ The group-level NRA therefore enjoys some discretion in determining the scope of the bank in the mapping process (via the "written arrangements") and the assessment of materiality of distinct parts of the group. Other special functions of the group-level NRA relate to its representative functions vis-à-vis the bank, EU bodies and third country authorities [19 Art. 51].

Second, resolution colleges have a role in relation to safeguarding the critical functions of cross-border functions of the bank, which can be described as the participating NRAs' "European" mandate. ${ }^{14}$ In the strictly national context bank critical functions include deposit-taking, lending activities and payment services "since they are provided to a limited number of third parties and can be replaced in an acceptable manner and within a reasonable timeframe" [48]. The BRRD's extension of the notion of critical functions crossborder is in stark contrast to another key concept of EU resolution law, namely "public interest in financial stability", which remains primarily national [20 paras. $111-115] .{ }^{15}$ As a consequence, the definition of critical cross-border functions of the bank is one of the main tasks unique to cooperation in cross-border colleges, since individual NRAs would hardly be able to determine these unilaterally. Experts have suggested that such functions include the smooth operation of payment systems and continued access to essential banking services" [35 p. 373].

The final multilevel aspect of college functioning arises in the context of the role played by the EU (supranational) agency - the EBA. Such a role has three facets. First, the EBA is the rule-maker, that is through ever more granular procedural requirements established in line with the BRRD, it constrains the operation of the colleges. Secondly, as member of all the colleges, the EU agency ensures consistency across their operation. Finally, through its mediation

\footnotetext{
13 Art. 50 Resolution College RTS, which provides that "[f]or the purposes of identifying the members and potential observers of the resolution college, the group-level resolution authority shall conduct the mapping of group entities referred to in Article 1(1) of Directive 2014/59/EU (...).".

14 Art. 2(1)(35) BRRD for the definition of critical functions including the cross-border aspect. On the "European mandate" in resolution colleges see European Parliament [29].

15 Further on state aid to banks after the establishment of the Banking Union see Nicolaides [43].
}

mandate, EBA is tasked with solving disputes between the authorities, which preclude joint decision-making.

\section{European Banking Authority (EBA)}

The EBA is an EU networked agency consisting of the 27 national banking supervisors, endowed with the secretariat to act independently and in the interest of the Union [26 Recitals 42 and 52]. Its resolution mandate is exercised by the dedicated ResCo (Resolution Committee) established within the agency. ResCo is composed of a Chairperson and the heads of the 27 EU NRAs, with observers from resolution authorities of the EEA EFTA countries represented in the EBA Board of Supervisors (BoS), representatives of the European Commission, the SRB, the European Systemic Risk Board, the European Central Bank (SSM), the European Securities and Markets Authority (ESMA) and the European Insurance and Occupational Pension Authority (EIOPA). ${ }^{16}$ The ResCo is a permanent structure which-unlike resolution colleges or the variable Executive Board of SRB discussed below-has a permanent membership and is not concerned with a particular bank.

In the context of cross-border banking, the EBA has a general coordination function "in particular in situations where adverse developments could potentially jeopardise the orderly functioning and integrity of financial markets or the stability of the financial system in the Union" [26 Art. 32]. ${ }^{17}$ In the context of resolution colleges specifically EBA is meant to improve the convergence and consistency of their decisions [24 Art. 88(4)]. Such a contribution is made by issuing best practice documents, guidelines to complement the Single Rulebook, leadership and action plans as well as IT platforms [21 p. 48]. In last resort scenarios, EBA may also act as a mediator and an arbiter between NRAs. ${ }^{18}$ Such mediation can be entered into on the request of a national authority part of a college, and is binding on

\footnotetext{
16 Article 127 BRRD requires the EBA to create a permanent internal committee for the purpose of preparing EBA decisions to be taken in accordance with Article 44 of the EBA Regulation, the relevant decisions of the EBA are still taken by the Board of Supervisors of the agency.

17 Such a function, includes-as provided for in the resolution planning procedure under Art. 13(4) BRRD "carrying out non-binding mediation upon a request from the competent authorities or on its own initiative".

18 Decision of the European Banking Authority on the settlement of a disagreement [16], where the EBA indicated that the draft 2017 Resolution Plan does not establish that the potential impediments are-or are not-material impediments or substantive impediments to resolvability for the purposes of the BRRD. More generally, "it appear[ed] to the EBA that the various elements in the draft 2017 Resolution Plan do not individually or in combination satisfy the requirements for an assessment of impediments as required by the above legislative provisions".
} 
the parties affected (except where the matter impinges on fiscal matters). These powers are intended to address a specific lacunae in the governance framework identified by the de Larosière report in 2009, whereby during the financial crisis the NRAs did not have a formal route to challenge the decisions of authorities in the Member State where a different part of the bank was established, even if these affected directly the position of the legal entity in their jurisdiction. As a result, governance problems in cross-border groups were aggravated [ 9 p. 23, 13 p. 73]. Early examples of EBA mediation suggest that it has been resorted to by non-euro area hosts of EBU-based banks. In 2018, EBA mediated on a case involving a Romanian subsidiary, whose resolution authority disagreed with the resolution planning approach of the group-level authority (SRB). EBA's solution was to focus predominantly on the procedure, which is meant to ensure that all the concerns of various authorities are properly addressed in the group-level decision-making processes [47 s. 2.46 for discussion].

\section{Single Resolution Mechanism (SRM) and the Single Resolution Board (SRB)}

In comparison to the resolution colleges, the EBU structure established for the purpose of administrative cooperation in the area of resolution law-the SRM-is more integrated. The SRM is composed of NRAs of participating Member States and the SRB, a "specific" EU agency endowed with centralised decision-making powers and a legal personality [28 Art. 42(1), 6 and 51 p. 169-204 on SRB]. ${ }^{19}$ The SRM becomes the "national" authority for the purpose of the resolution-related tasks. ${ }^{20}$ The interaction between the NRAs and SRB is regulated by the SRM Regulation and rules of procedure which apply generally-no bespoke "written arrangements" as in the case of resolution colleges-are necessary [47 p. 43, 49 for the Framework for Cooperation between the SRB and NRAs]. The NRAs thus have a greater and more predictable access to information within this form of cooperation, which is not conditional on the good-will of the group-level NRA. Furthermore, while the EBA still has a role as the rule-maker with regard to the SRM, any conflicts between the authorities are internalised and to be solved by the SRB's Appeal Panel.

The SRB is the owner of the Single Resolution Fund (SRF), that is the fund to which banks themselves contribute, which can finance resolution in cases of a credit institution's

\footnotetext{
19 Comparatively with EBA as another key actor in the EU banking landscape see Božina Beroš [5].

${ }^{20}$ As pointed out by Gortos, this is done as if in passing via recital 91 SRM Regulation. For a comment on the overall design see Gort$\operatorname{sos}[34]$.
}

failure. Such funds are also established on the national basis under the BRRD. They then amount to $1 \%$ of covered deposits paid by local banks with contributions collected and administered at the national level. In the EBU, however, the national funds become mutualised under the 2014 Intergovernmental Agreement accompanying the creation of the SRM. In addition to creating a joint fund-which is meant to solve problems of loss-allocation for cross-border bank groups-the SRF is the source of a key difference with the NRA-based college arrangements described above, namely that the individual bank contributions to the SRF are determined at a centralised level by the SRB ${ }^{21}$ Thus, it is the EU agency which becomes the main interlocutor of the entities within the bank in this regard. Further, if the banks disagree with an SRB decision, they no longer have recourse in the national legal system: any disagreement with regard to the contribution amount set, but also specific components of the resolution plans, is within the exclusive jurisdiction of the CJEU [37].

The multilevel cooperation within the specific administrative crisis prevention procedures is more integrated in the SRM than in the resolution colleges. The SRB takes the decisions on group resolution plans for bank groups established in one of the participating Member States. However, additional complexity is to be identified here. First, the NRAs may assist in the process, meaning the procedure is rather composite than centralised [28 Art. 7-8, 15 for an analysis of the composite administrative procedures]. In fact, the local jurisdiction continues to play a key role, for example, with regard to setting the MREL requirement within the group (internal MREL), where certain forms of cross-border guarantees are excluded within the EBU, as well as in the EU [24 Arts. 45b and 45f, 28 Arts. 12c and 12g]. On the other hand, the SRB in preparing the group resolution plans is to look specifically at the EU scope of the bank, rather than purely its EBU-located entities. ${ }^{22}$

With regard to crisis management, the SRM creates a mandatory framework for implementation of the resolution schemes once a bank is deemed failing or likely to fail. The SRB becomes the NRA responsible for determining whether the public interest and critical functions tests have been met to put a bank in resolution (rather than insolvency). In contrast to the resolution colleges, the EBU resolution procedures do not allow for defection by national authorities, even if the decision-making procedures involving the Council and the European Commission to settle on the amount of SRF used, are particularly cumbersome [28 Art. 18]. The SRM

\footnotetext{
${ }^{21}$ Following EU-wide rules set down in Commission Delegated Regulation (EU) 2015/63 [18].

${ }^{22}$ Compare Art. 12 BRRD2 Regulation for EU-wide arrangements and Art. 8(10) SRM2 Regulation for EBU ones.
} 
is not, however, fully centralised. Three specific features add to the complexity along the vertical dimension of cooperation primarily, namely the variability of the SRB's Executive Board composition, the reliance on the NRAs for decision implementation and the differentiated position of the noneuro area NRAs within the EBU more broadly

With regard to the first point, the core of the SRM has a variable composition, depending on the bank with regard to which it takes a particular decision. The SRB's Executive Board is composed of five full-time members [28 Art. 43(1)] and the NRAs of the Member States where the bank in question is established, as well as those where it has subsidiaries. $^{23}$ This variability is a result of the dominant role of the NRAs in the implementation of resolution procedures. Due to the limitations set by the Meroni doctrine of the Court of Justice in terms of the powers that may conferred on an EU agency, the SRB relies exclusively on the NRAs for the implementation of specific decisions taken vis-à-vis the bank group, including any sanctions. While greater coordination in the case of cross-border bank groups may be achieved through centralised decision-making, the trust issue which arises horizontally in the context of resolution colleges, is here reproduced vertically; in addition, the SRB has few tools of coercion vis-à-vis the NRAs. ${ }^{24}$

The final caveat of the SRM as a multilevel administrative structure relates to the inadvertently differentiated position of the non-euro States who decide to participate in the EBU, now a practical consideration given that Bulgaria and Croatia entered into close cooperation in October 2020, while others such as Denmark or Sweden consider joining the EBU without the prospect of joining the common currency. At first glance such a differentiation between euro and non-euro participating Member States might be surprising, given that SRM is an internal market measure established on the basis of Art. 114 TFEU and the SRB is an EU agency. In fact-unlike in the SSM-no dedicated arrangement is necessary to provide for the inclusion of non-euro States in the decision-making procedures of the SRM when they enter into close cooperation. ${ }^{25}$ However, the position of the noneuro States within the SRM differs in at least two respects,

\footnotetext{
${ }^{23}$ Note as well that SRM2 has strengthened the voting powers of the permanent members. See Asimakopoulos [2, pp. 279-300].

${ }^{24}$ Critically on the internal organisation principles of the SRM in the context of resolution scheme implementation (i.e. when a bank is deemed failing or likely to fail) see Busch [7] and Lintner [38].

25 Binder has suggested that the automatic and formally equal standing of euros and non-euros within the SRM is problematic in the light of possible different incentives to cooperate and perhaps even paradoxical given the higher reliance of SRM on fiscal cooperation. However, as Nieto and Singh show, in the case of Bulgaria and Croatia such risks are unlikely to materialise in the light of the broad safety nets in these countries as well as subsidiary-based banking structure, see Binder [3].
}

namely the operation of the safety net and the powers of the SRB vis-à-vis the NRAs.

The first aspect involves two components relating to the public support which banks from outside the euro area, but within the EBU, can rely on in a crisis. With the entry into the SRM, the non-euro Member State's banking system becomes part of the Single Resolution Fund framework established at the EBU level. However, the access to the fiscal backstop of the European Stability Mechanism (ESM) remains restricted. In December 2020, the Eurogroup approved a revised ESM Treaty, which creates the common backstop to the SRF, should its needs exceed the collected contributions. The ESM, however, is an explicitly euro area-only endeavour (created as a stabilisation function outside of the EU Treaty). The revised ESM Treaty includes provisions for the participation of non-euro area Member States, who have to provide parallel credit lines to the SRF alongside the ESM. Such countries would then gain partial access to the ESM information [10 Recital 9A and Art. 5(4), 40, 42]. Further differentiation arises in the context of the EBU procedures involving the European Central Bank (ECB). Whereas in the context of crisis management measures (recovery and resolution), the banks from the euro area participating Member States may rely on the liquidity and firepower of the ECB (notwithstanding the "Chinese walls", equally the supervisor and the monetary policy authority), the non-euro States have only their local central banks to lean on. As a consequence, in the light of a more restricted safety net, the reliance of non-euro SRM members on the joint crisis prevention procedures may well be greater than for the euro area NRAs.

The second aspect relates to the specific powers which the SRB has vis-à-vis the non-euro NRAs, and not the euro area ones. Should close cooperation in the EBU be terminated, the SRM regulation provides for a disentangling of the noneuro participating Member State involvement in the SRF (no such provision is made for the euro area NRAs). In such cases, the SRB "shall decide within three months after the date of adoption of the decision to terminate close cooperation, in agreement with that Member State, on the modalities for the recoupment of contributions that the Member State concerned has transferred to the Fund and any conditions applicable" [28 Art. 4(3)]. The specific powers of the SRB in this regard are unique, and serve to highlight the point that for the non-euro States participation in the EBU is reversible and conditional.

Consequently, the difference between the non-euro and euro area Member States within the SRM relates primarily to the stability of cooperation and the interaction with other pillars of EBU as well as links with broader euro area economic governance (see Table 1 for summary). Such factors may well have a bearing on incentives to cooperate and the level of trust established between the NRA and the SRB in 
Table 1 Multilevel administrative cooperation in the EBU and EU cross-border bank group resolution

\begin{tabular}{|c|c|c|c|}
\hline & EU resolution college & $\begin{array}{l}\text { SRM (euro area partici- } \\
\text { pating Member States) }\end{array}$ & $\begin{array}{l}\text { SRM (all par- } \\
\text { ticipating Member } \\
\text { States) }\end{array}$ \\
\hline Permanence of cooperation & Cyclical & Permanent & Conditional \\
\hline $\begin{array}{l}\text { Procedure outcome (in resolu- } \\
\text { tion planning) }\end{array}$ & Joint decision & SRB decision & SRB decision \\
\hline Implementation & NRAs & NRAs & NRAs \\
\hline Internal conflict resolution & EBA & SRB Appeal Panel & SRB Appeal Panel \\
\hline Backstop (crisis safety net) & National & EBU/euro area & EBU/national \\
\hline Remedies & National & CJEU/national & CJEU/national \\
\hline
\end{tabular}

particular, adding to the complexity of the overall multilevel administrative design.

\section{Explaining the outcomes of multilevel administrative cooperation}

There is little empirical evidence that the more centralised multilevel administrative structure of the SRM is more successful in attaining the goals of cross-border resolution, that is achieving efficient, fair and timely solutions for the group, while protecting financial stability in all the Member States where the group operates [24 Recital 97] and ensuring continuity of critical functions, including those of cross-border nature [24 Art. 2(1)(35) and Art. 31(1)(2), $36]$, than looser arrangements such as resolution colleges. This observation extends as well to the crisis preparation measures, where banks operating EU-wide are no less likely to have integrated (SPOE) resolution strategies, than those active within the EBU. In the light of the preceding analysis, are there specific aspects of the individual multilevel cooperation arrangements which explain their relative successes or shortcomings in terms of creating a framework within which effective cross-border resolution is possible without market fragmentation? In other words, can we identify specific features of multilevel administrative cooperation which are more conducive to constructive engagement and trustbuilding among the authorities involved, where these are necessary condition for a successful cross-border resolution? This section discusses some explanations.

The apparent success of resolution law (in terms of number of resolution cases) outside of the scope of the EBU, may be partially explained by two circumstantial factors. First, it may be too soon to assess the progress made by the SRB, operational only since 2015 . Though indeed some experts have pointed to the less positive experiences of NRAs working within the SRB [31 p. 37], these may well be evidence of a steep learning curve. Where a lack of trust between NRAs and SRB is caused by disagreements over definitions, further experience in intra-SRM cooperation and the SRB's internal capacity-building could help overcome them. Second, the choice of resolution strategies (e.g. the fully integrated SPOE) may be explained by cross-border bank group's business choices rather than the applicable administrative cooperation arrangement. Specifically, the EU cross-border banks in fact operate largely between the euro area and the Nordics (Sweden, Denmark) or the Central, Eastern and South-Eastern Europe (Czechia, Poland, Romania, Bulgaria) [31]. In other words, an apparent success of resolution colleges in achieving cooperative outcomes (i.e. integrated resolution strategies) is the consequence of the market structure, rather than its cause. There are just more EU cross-border bank groups, than the EBU ones. The institution of centralised oversight-either for supervision or resolution-has not (yet) changed that.

From the perspective of EU administrative law, however, it may be that the SRM's design (even with the heterogeneity inbuilt), exasperates rather than assuages the homehost conflicts between Member States, in particular in the absence of a third-party arbiter, such as the EBA in the context of resolution colleges. Theoretically, joining the SRM should ensure that the interests of different NRAs are better represented in the overall approach of the SRB. However, scholars and experts have pointed out that this arrangement, especially where the subsidiaries in the smaller economies are nominally not significant in the overall balance sheet of the cross-border bank, might result in small host NRAs' concerns becoming an afterthought in the SRB's approach, with the only recourse available being the SRB's Appeal Panel $[39,47]$. However, this route does not appear effective in resolving intra-SRM conflicts. For example, in 2018, the SRB Appeal Panel ruled in a case where the SRB was accused of failing to determine the MREL requirement at the level of an individual entity within a cross-border group (it had done so only at the consolidated group level). The Appeal Panel stated it had no competence to hear actions for SRB's failure to act, suggesting full administrative integration comes at a cost of protective elements for the hosts. ${ }^{26}$ The role of the Appeal Panel is, therefore, quite

\footnotetext{
${ }^{26}$ See Final Decision of Case 8/18 [50]. The Appeal Panel held that the imposition of an MREL requirement at the consolidated rather than the individual level, it was held that the mere existence of a
} 
different from that of EBA which-given the convergence and mediation mandate-is oriented towards outcomes which are mutually acceptable to the parties involved. At the same time, even though the design of the SRM, therefore, is less sensitive to possible internal jurisdictional and interest conflicts than the colleges, it nonetheless relies significantly on NRAs. Further, the substantive tests applied in resolution law and in the adjacent areas of law (e.g. insolvency) continue to be national. In such a context centralisation which risks reduced sensitivity to local financial stability concerns, may subsequently reduce trust between authorities necessary for a successful implementation of resolution within the SRM. In the light of insufficient conflict management arrangements, the result may be only exasperated internal conflict and bureaucratic politics, which appears to be a serious impediment at the heart of the SRM.

\section{Conclusions}

This article has analysed comparatively the multilevel administrative cooperation established for bank crisis prevention and management in the EU and the EBU. It has grappled with the complexity of the resolution colleges and the SRM in order to explain why it appears that looser arrangements may well be more conducive to cooperative outcomes than centralised ones, or at least no less effective in making for cooperative cross-border resolution outcomes. Specifically, the limitations of the SRM, in terms of constrained implementation powers of the SRB as well as the differentiated position of the non-euro Member States, were discussed as evidence of inherent tensions within the integrated mechanism. On the other hand, resolution colleges were shown to be much more formalised (and centralised) than they appear at first glance. Such findings, developed from an EU administrative law perspective, raise questions of a constitutional nature, in particular relating to accountability of such administrative cooperation, equality of Member States and the implications of Meroni doctrine's distortive effects.

With regard to the accountability question, concerns emerge with regard to the absence of democratic control over the colleges and the group-level NRAs. Since the colleges are not formally decision-making bodies, and the NRAs are embedded in the domestic constitutional settings, few

\section{Footnote 26 (continued)}

requirement that MREL be imposed on an individual level does not imply it may not be imposed on a consolidated level. Failure of the SRB to impose a requirement at an individual level amounts to a failure to act, for which the appeal board has no competence [50 paras. 45-48]. Notably, the CJEU has interpreted narrowly such actions [52]. provisions have been made in the BRRD to create a framework within which they could be called to answer for the effects of their actions. An exception is the accountability of colleges vis-à-vis EBA, which appears altogether insufficient given the limited (non-binding) nature of any control exercised by the agency [24 Art. 88(4) and 18(5) on EBA mediation specifically for EBA's role in relation to colleges]. Greater public accountability over their operation, including by establishing greater transparency, is therefore warranted.

With regard to the question of equality, the problem here might not arise necessarily in the context of differentiation between euro and non-euro Member States in the EBU, discussed above. It may well be, as argued by Tridimas, that "equality of opportunity" suffices to satisfy the demands of non-discrimination [53 pp. 25-48], even if-given the Art. 114 TFEU legal basis for the SRM, i.e. internal market-wide harmonisation-such claims should be treated with caution in this case. If the EBU is indeed to be conceived of as a predominantly euro area institution, discussions of differentiation may well highlight that a separate legal basis for EMU's financial sector regulation harmonisation is necessary. The problem of equality which arises in the context of the themes explored in this article is rather the assumption that the administrative structure established-either for the EU as a whole or within EBU-on bespoke terms for the individual banks, is to necessarily mirror the corporate structure, with the administrative powers distributed differently depending on whether the NRA is responsible for the parent, subsidiary or branch, in addition to any differentiation arising from membership of the currency union. While such a model centred around the consolidated (group-level) supervisor might have been suitable for the predominantly intergovernmental arrangements which preceded the crisis, in the context of highly integrated administrative structures, it raises concerning the relative position of distinct NRAs, in particular in the absence of local safeguards.

Finally, where the Meroni doctrine continues to be a thorn in the SRM's side, this article has highlighted the extent to which the limits on SRB's powers together with the prevalence of jurisdictional divisions, continue to be not only a curb on the effectiveness of the centralised regime, but also a source of potential distortions. At the same time, any greater centralisation, including greater powers with regard to overriding jurisdictional divisions within the EBU which might help improve the effectiveness of centralised administrative arrangements, should be complemented with targeted efforts oriented at building up trust between different administrative levels and towards the agency itself.

Funding Open access funding provided by European University Institute - Fiesole within the CRUI-CARE Agreement. 


\section{Declaration}

Conflict of interest The author states that there is no conflict of interest.

Open Access This article is licensed under a Creative Commons Attribution 4.0 International License, which permits use, sharing, adaptation, distribution and reproduction in any medium or format, as long as you give appropriate credit to the original author(s) and the source, provide a link to the Creative Commons licence, and indicate if changes were made. The images or other third party material in this article are included in the article's Creative Commons licence, unless indicated otherwise in a credit line to the material. If material is not included in the article's Creative Commons licence and your intended use is not permitted by statutory regulation or exceeds the permitted use, you will need to obtain permission directly from the copyright holder. To view a copy of this licence, visit http://creativecommons.org/licenses/by/4.0/.

\section{References}

1. Angeloni, I. 2020. Beyond the pandemic: reviving Europe's Banking Union. London, UK: Centre for Economic Policy Research.

2. Asimakopoulos, I.G. 2019. The single resolution board as a new form of economic governance. In The metamorphosis of the european economic constitution, ed. C.H. Hofmann, K. Pantazatou, and G. Zaccaroni. Cheltenham: Edward Elgar Publishing.

3. Binder, J. H. 2019. Close cooperation within the SRM: centralised decision-making, decentralised implementation-shared responsibilities. Frankfurt am main, Germany. EBI Working Paper series no. 46.

4. Black, J. 2012. Restructuring global and EU financial regulation: character, capacities and learning. In Financial regulation and supervision: a post-crisis analysis, ed. E. Wymeersch, K.J. Hopt, and G. Ferrarini. Oxford: Oxford University Press.

5. BožinaBeroš, M. 2018. Agencies in European banking: a critical perspective. New York: Springer.

6. BožinaBeroš, M. 2018. Some reflections on the governance framework of the single resolution board. Journal of Common Market Studies 56 (3): 646-655.

7. Busch, D., B.J. Van Rijn, and M. Louisse. 2019. How single is the single resolution mechanism? European Business Law Review 30 (4): 577-615.

8. Calmfors, L., and P. Englund. 2020. Financial regulation and macroeconomic stability in the Nordics. Nordic Economic Policy Review 2020: 7-20.

9. Carmassi, J., and R. Herring. 2016. The corporate complexity of global systemically important banks. Journal of Financial Services Research 49 (2-3): 175-201.

10. Consolidated Version of the Treaty establishing the European Stability Mechanism. 2 February 2012, https://www.esm.europa.eu/ sites/default/files/20150203_-_esm_treaty_-_en.pdf.

11. Culpepper, P., and T. Tesche. 2020. Death in Veneto? European banking union and the structural power of large banks. Journal of Economic Policy Reform 24 (2): 134-150.

12. Czerniak, A. and A. Smoleńska. 2019. Poland without the euro-a cost benefit analysis. Warsaw, Poland: Polityka Insight Report.

13. De Larosière, J. 2009. The high-level group on financial supervision in the EU. Report. Brussels, Belgium, 25 February 2009.

14. Draghi, M. 2018. Risk-reducing and risk-sharing in our Monetary Union. Speech at the European University Institute. Florence, 9 May.
15. Eckes, C., and R. D. Ambrosio. 2020. Legal Working Paper Series Composite administrative procedures in the European Union. Frankfurt am main, Germany. Working Paper no. 20.

16. European Banking Authority. 2018. Decision of the European Banking Authority on the settlement of a disagreement addressed to Single Resolution Board and Banca Naţională a României. London, UK. Decision of 27 April 2018.

17. European Banking Authority. 2020. Resolution Colleges-Annual Report 2019. London, UK. EBA Report no. 24.

18. European Commission Delegated Regulation (EU) 2015/63 of 21 October 2014 supplementing Directive 2014/59/EU of the European Parliament and of the Council with regard to ex ante contributions to resolution financing arrangements. OJ L 11, 17 January 2015, pp. 44-64.

19. European Commission Delegated Regulation (EU) 2016/1075 of 23 March 2016 supplementing Directive 2014/59/EU of the European Parliament and of the Council with regard to regulatory technical standards specifying the content of recovery plans, resolution plans and group resolution plans, the minimum criteria that the competent authority is to assess as regards recovery plans and group recovery plans, the conditions for group financial support, the requirements for independent valuers, the contractual recognition of write-down and conversion powers, the procedures and contents of notification requirements and of notice of suspension and the operational functioning of the resolution colleges. OJ L 184, 8 July 2016, pp. 1-71 ("Resolution College RTS").

20. European Commission. 2013. Commission Decision on State Aid to Hypo Group Alpe Adria. Case SA. 28487, 5 February 2013

21. European Court of Auditors. 2014. European Banking Supervision Taking Shape - EBA and Its Changing Context. Luxembourg, Luxembourg. Special Report no. 05.

22. European Parliament and Council Directive (EU) 2019/879 of the European Parliament and of the Council of 20 May 2019 amending Directive 2014/59/EU as regards the loss-absorbing and recapitalisation capacity of credit institutions and investment firms and Directive 98/26/EC. OJ L 150, 7 June 2019, pp. 296-344 ("BRRD 2").

23. European Parliament and Council Directive 2014/49/EU of 16 April 2014 on deposit guarantee schemes. OJ L 173, 12 June 2014, pp. 149-178.

24. European Parliament and Council Directive 2014/59/EU of 15 May 2014 establishing a framework for the recovery and resolution of credit institutions and investment firms and amending Council Directive 82/891/EEC, and Directives 2001/24/EC, 2002/47/EC, 2004/25/EC, 2005/56/EC, 2007/36/EC, 2011/35/ EU, 2012/30/EU and 2013/36/EU, and Regulations (EU) No 1093/2010 and (EU) No 648/2012, of the European Parliament and of the Council. OJ L 173, 12 June 2014, pp. 190-348 ("BRRD").

25. European Parliament and Council Regulation (EU) 2019/877 of 20 May 2019 amending Regulation (EU) No 806/2014 as regards the loss-absorbing and recapitalisation capacity of credit institutions and investment firms. OJ L 150, 7 June 2019, pp. 226-252 ("SRM Regulation 2").

26. European Parliament and Council Regulation (EU) No 1093/2010 of 24 November 2010 establishing a European Supervisory Authority (European Banking Authority), amending Decision No 716/2009/EC and repealing Commission Decision 2009/78/EC. OJ L 331, 15 December 2010, pp. 12-47 (“EBA Regulation”).

27. European Parliament and Council Regulation (EU) No 575/2013 of 26 June 2013 on prudential requirements for credit institutions and investment firms and amending Regulation (EU) No 648/2012. OJ L 176, 27 June 2013, pp. 1-337 (“CRR Regulation”).

28. European Parliament and Council Regulation (EU) No 806/2014 of 15 July 2014 establishing uniform rules and a uniform procedure for the resolution of credit institutions and certain 
investment firms in the framework of a Single Resolution Mechanism and a Single Resolution Fund and amending Regulation (EU) No 1093/2010. OJ L 225, 30 July 2014, pp. 1-90 (“SRM Regulation").

29. European Parliament. 2019. Banking Union: Defusing the 'home / host' debate. Economic Governance Support Unit PE 634.373.

30. Fernández Fernández, J.A. 2020. Considerations of the SPE and MPE resolution. Journal of Banking Regulation 21 (3): 278-287.

31. Financial Sector Advisory Center. 2019. Banking Supervision and Resolution in the EU: Effects on Small Host Countries in CEE and SEE. Washington, DC. World Bank Group Annual Report 2019

32. Gardella, A. 2016. La Risoluzione Dei Gruppi Finanziari CrossBorder Nell'Unione Europea. Rome, Italy: Banca d'Italia. Quaderni di ricerca giuridica, Scritti sull'Unione Bancaria no. 81.

33 Gordon, J.N., and W.-G. Ringe. 2015. Bank Resolution in Europe: The Unfinished Agenda of Structural Reform. In The European Banking Union, ed. D. Busch and G. Ferrarini. Oxford: Oxford University Press.

34. Gortsos, C. 2019. The Single Resolution Mechanism (SRM) and the Single Resolution Fund (SRF): Legal Aspects of the Second Main Pillar of the European Banking Union. April 30, 2019. https://ssrn.com/abstract=2668653.

35. Hofmann, H. 2009. Composite decision making procedures in EU administrative law. In Legal challenges in EU administrative law: Towards an integrated administration, ed. H. Hofmann and A. Türk. Cheltenham: Edward Elgar Publishing.

36. Hüpkes, E. 2009. Form follows function - A new architecture for regulating and resolving global financial institutions. European Business Organization Law Review 10 (3): 369-385.

37. Iccrea Banca SpA v Banca d'Italia (2019) ECLI:EU:C:2019:1036.

38. Lehmann, A. 2019. Impediments to resolvability of Banks. Economic Governance Support Unit PE 634.360

39. Lintner, P. 2017. De/centralized decision making under the European resolution framework: does Meroni hamper the creation of a European resolution authority? European Business Organization Law Review 18 (3): 591-616.

40. Lupinu, P.M. 2020. Exploring governance issues between the SRB and the ESM in the use of the Common Backstop. University of Luxembourg, Faculty of Law Economics and Finance. Working Paper no. 021.

41. Maragopoulos, N. 2020. Removing the regulatory barriers to cross-border banking financial stability in the Banking Union. Speech at the European University Institute event on 'Bank Resolution in times of COVID-19'. Virtual event, 27 November.

42. Markakis Menelaos in this special issue.

44. Nieto, M.J. and D. Singh. 2021. Incentive Compatible Relationship between the ERM II and Close Cooperation in the Banking Union: The Cases of Bulgaria and Croatia (mimeo).

45. Parchimowicz, K.M. 2019. Missed targets and misplaced incentives? The case of parent undertaking requirement in the USA and in the EU. Journal of Banking Regulation 21 (3): 212-223.

43. Phedon Nicolaides in this special issue.

46. Schnabel, I., and N. Véron. 2018. Completing Europe's banking union means breaking the bank-sovereign vicious circle. VoxEU Blog, 16 May.
47 Singh, D. 2020. European cross-border banking. Oxford: Oxford University Press.

48. Single Resolution Board. 2017. Notice summarising the effects of the decision taken in respect of Banca Popolare di Vicenza S.p.A. SRB Summary Notice. Brussels, Belgium. 23 June 2017, https:// srb.europa.eu/sites/srbsite/files/23.6.2017_summary_notice_ banca_popolare_di_vicenza_s.p.a._20.00.pdf.

49. Single Resolution Board. 2018. Decision of the Single Resolution Board of 17 December 2018 establishing the framework for the practical arrangements for the cooperation within the Single Resolution Mechanism between the Single Resolution Board and National Resolution Authorities. Brussels, Belgium. Decision of the Plenary Session no. 15.

50. Single Resolution Board. 2018. Final Decision of Case 8/18 Appeal Panel of the Single Resolution Mechanism. Brussels, Belgium. 16 October 2018, https://srb.europa.eu/sites/srbsite/ files/case_8_18_decision_anonymised.pdf.

51 Smoleńska, A. 2019. Single Resolution Board: Lost and Found in the Thicket of EU Bank Regulation. In The European Banking Union and Constitution: beacon for advanced integration or death-knell for democracy, ed. S. Grundmann and H.W. Micklitz. Oxford: Hart Publishing.

52. SV Capital OÜ v European Banking Authority (EBA) (2016) ECLI:EU:C:2016:947.

53 Tridimas, T. 2019. The Constitutional Dimension of Banking Union. In The European Banking Union and Constitution: beacon for advanced integration or death-knell for democracy, ed. S. Grundmann and H.W. Micklitz. Oxford: Hart Publishing.

54. Troiano, E. 2015. Cross-border cooperation between resolution authorities in the BRRD. In Research handbook on crisis management in the banking sector, ed. M. Haentjens and B. Wessels. Cheltenham: Edward Elgar Publishing.

Publisher's Note Springer Nature remains neutral with regard to jurisdictional claims in published maps and institutional affiliations.

Agnieszka Smoleńska is an associate researcher with the European Banking Institute and a senior EU affairs analyst at Polityka Insight, a policy analysis centre in Warsaw. Her academic research focuses on cross-border banking regulation, economic governance and sustainable finance in the EU. In 2020 she defended her PhD in Law at the European University Institute. She worked at the European Commission, the European Parliament and the Florence School of Banking and Finance and contributed to research projects on the ECB (with Transparency International) and regulatory centralisation in EU financial regulation (Robert Schuman Centre for Advanced Studies). Her work appeared in a number of edited volumes on EU financial regulation published among others with Hart Publishing and Oxford University Press. 